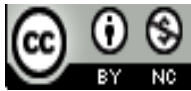 \\ Jurnal Terapan Manajemen dan Bisnis is licensed under \\ A Creative Commons Attribution-Non Commercial 4.0 International License.
}

\title{
OSING CULTURE CONSERVATION IN PERSPECTIVE CORPORATE SOCIAL RESPONSIBILITY
}

\author{
Ratna Wijayanti Daniar Paramita1), Noviansyah Rizal2), Muchamad Taufiq ${ }^{3)}$, Muhaimin \\ Dimyati $^{4)}$
}

1) STIE Widya Gama Lumajang, Lumajang, Indonesia E-mail: pradnyataj@gmail.com

2) STIE Widya Gama Lumajang, Lumajang, Indonesia E-mail: pradnyataj@gmail.com

3) STIE Widya Gama Lumajang, Lumajang, Indonesia E-mail: pradnyataj@gmail.com

4) STIE Widya Gama Lumajang, Lumajang, Indonesia E-mail: pradnyataj@gmail.com

\begin{abstract}
This research is a qualitative research that uses an ethnomethodology approach to study the preservation of Osing culture in Banyuwangi in academic texts. At present, the Government of Banyuwangi packs a variety of indigenous cultures and cultures in an event known as Banyuwangi Festival, an event that invites both domestic and foreign audiences. Meanwhile, cultural actors with all the limitations of their funds are trying to maintain the indigenous culture that has taken root in their village by establishing a cultural studio that is funded independently. Local companies have mostly channeled social responsibility funds but not in the form of social culture. The results of this study which was also the result of the Focus Discussion Group (FGD) forum were agreed that local companies would channel cultural CSR funds by providing direct guidance to cultural actors or cultural studio owners. As the implementation of the policy, the agreement is then stated in the academic text sheet.
\end{abstract}

Keywords: Cultural actors; Fund-flow model; Preservation of indigenous culture; Academic texts

\section{Introduction}

Until now, the people's understanding of the cultural values of the Osing people is still very strong. Communities with high cultural awareness and spirit play a role in traditional ceremonies carried out routinely. For example, mocolontar which is held every Wednesday night, the tumpengsewu, seblang, iderbumi, kebo-keboan. The culture that has been attached to them is seen as a collection of patterns of human behavior by relying on creativity and confidence for the necessities of life so that the culture of ancestral heritage continues to be 
carried out today. Preservation of culture is not only indigenous culture but also art culture is still being preserved through the introduction of children and through performance performed by art studios which are widely available in Kemiren and other villages. However, the existence of studios that are mostly owned by individuals still does not have sufficient completeness both for training and for performances. Therefore, the owner of the art studio and cultural actors are in dire need of funds for the development of the studio they own, whether for equipment, costumes or for training and staging activities.

Local companies in Banyuwangi have partially carried out their obligations to issue CSR, others have not. The CSR that has been issued by the company for the social community is in the form of partnership programs, making public infrastructure facilities, for education and also for culture. But the usefulness of cultural development is still not felt by cultural actors and studio owners.

Some other things based on this research are secondary data that researchers get through relevant agencies, which is the result of the first year research, namely that Banyuwangi District already has regional regulations on CSR namely Banyuwangi District Regulation Number 3 of 2014 concerning Corporate Social Responsibility and Regulations Banyuwangi District Head number 43 of 2015 concerning Implementation Guidelines for Banyuwangi District Regulation Number 3 of 2014 concerning Corporate Social Responsibility. The Regional Government has set a tourism village through Local Regulation number 1 of 2017 concerning Tourism Villages and the Regional Government has determined the Kemiren Village as a Tourism Village. This determination is because Kemiren Village is the only village whose people still carry out the ritual as a whole.

This study aims to implement the Corporate Social Responsibility (CSR) Model of culture as a model of the participation of local companies towards the preservation of Osing customary culture in Banyuwangi in the form of submitting academic texts as a basis for consideration of changes to the Regional Regulation on Corporate Social Responsibility.

There are several things that become the urgency of this research, namely: Customary culture in Banyuwangi which is diverse and becomes a cultural tradition that continues to be carried out by the community requires a lot of money so that the indigenous culture can continue to be preserved; Local companies must be able to provide real participation in the form of cultural CSR to preserve the Osing Tribal culture; the role of cultural CSR directly to cultural actors in the form of built studios is expected to help the development and preservation of culture so that a local regulation is needed that can protect these legal interests; the implementation of the cultural CSR model in the form of submitting academic texts as a basis for consideration of changes to the Regional Regulation on Corporate Social Responsibility.

\section{Research Methods}

This type of research is qualitative research that uses a case study approach. In this study, a case study approach was used to analyze the application of cultural Corporate Social Responsibility and the realization made by local companies towards the development of indigenous culture in the Glagah District around the company. This research will produce a research model in the form of academic manuscript products that will be submitted to local regulations by the DPRD.

The study was conducted with an inductive approach, at this stage, a research model will be produced in the form of academic script products that will be submitted to local regulations by the DPRD. This cultural CSR model will be applied by the sample companies 
so that it can be used to analyze the company's participation in cultural CSR towards the preservation of the Osing tribe's indigenous culture in future research.

\section{Results and Discussion}

The CSR fund-flow model presented in this study provides three alternative funds that can be applied. Alternatives that can be chosen and are expected to be truly channeled to cultural actors as well as the purpose of the company's participation in CSR Culture. Based on the results of the Focus Group Discussion which has been carried out an alternative model of the Cultural CSR fund flow, the chosen model is the flow of funds through the built studio.

This fund-flow model provides guidance to the art studio. This model will benefit the art studio more. Like CSR fund distribution for the development of small businesses, this model also has the purpose of growing and developing existing studios in order to continue to preserve indigenous culture and culture through the existing art studios. Existing studios always try to introduce art to elementary school-age children so that this art is not extinct. Some forms of recognition are through regular training and staging activities at studios. However, there are many limitations that have been complained about by the studio owners in being able to continue to exist and consistently perform this activity. One of them is the limitation in funding problems. The art in Banyuwangi that has been introduced to the public through the Banyuwangi festival must continue to be preserved. The initial step of preservation is through the development of cultural studios as cultural actors who act directly to preserve the culture of Banyuwangi.

Then the Focus Group Discussion which studies the implications of the implementation of the new system which will be regulated in the laws or regional regulations on aspects of community life and its impact on aspects of the country's financial burden. The Corporate Social and Environmental Responsibility of the Culture Sector has been carried out by several companies in Banyuwangi Regency, even from several companies that were respondents in the research on Potential Data Collection of the Funding and Mapping Sources of CSR Data in Banyuwangi Regency in 2017, each company has carried out social responsibility by donating to B-fest events. The problem is that the mechanism and form of implementation vary and not everyone, including the local government, knows the social responsibility activities that have been carried out. As a result, not a few parties stated that these companies had not carried out social responsibility activities.

In order to ensure the running of the Corporate Social and Environmental Responsibility program in Banyuwangi Regency goes well, it is necessary to make a law in the form of district regulations so that implementation in the field can run in accordance with the system that has been built so that all communities know and understand the parties who have carried out social responsibility. After the enactment of this regional regulation, a number of things will be felt by all residents in Banyuwangi Regency, including improvements in quantity and quality related to social welfare, recovery and/or improvement of environmental functions, health, education and spurring community-based quality economic growth. This happens because the budget burden that was previously borne by the regional government, with the enactment of this law, has been supported by the private sector so that the local government can concentrate on other fields that also require immediate treatment.

The continued effect of the enactment of this regulation is the reduced budget that must be spent by the Banyuwangi Regency government regarding the above. This reduction 
as a result of the entry of private companies into the above fields to help in accordance with the mandate of Law No. 40 of 2007 and Law No. 25 of 2007.

On the community side, of course with the enactment of this regional regulation, the community will get a positive impact both directly and indirectly. The direct result, for example, is getting a prize due to participation in a competition sponsored by one or several companies which are the Corporate Social and Environmental Responsibility program. On the other hand, the people, especially those who engage in cultural arts will also experience the indirect effects of the enactment of this regional regulation, among others, is the development of art studios managed by the community because they have "Foster Company" which previously developed slowly due to financing aspects and capital "love art alone "Which is the call of their soul.

The Regional Regulation on Corporate Social and Environmental Responsibility in the Field of Culture is based on the idea that the Company has a social responsibility towards stakeholders in all aspects of the company's operations that affect the welfare and prosperity of the community and the preservation of environmental functions. This responsibility requires a synergic relationship between the Regional Government, the Company and the community to realize the Corporate Social and Environmental Responsibility in the Field of Culture. Whereas the establishment of this Regional Regulation aims to provide legal certainty and protection for the implementation of the Corporate Social and Environmental Responsibility program in the Culture Sector, giving direction to the Company and stakeholders in preparing themselves to meet international standards; and synergizing the implementation of the Corporate Social and Environmental Responsibility in the Field of Culture with sustainable development programs in the Region while maintaining the preservation of environmental functions, economic growth and poverty reduction, organizing Corporate Social and Environmental Responsibility in accordance with the laws and regulations, minimizing the impact negative company presence and optimizing the positive impact of the company's existence; and programmed plans of the Regional Government to appreciate the business world that has carried out Corporate Social Responsibility by giving awards and providing convenience in administrative services.

The material regulated in the Regional Regulation on Corporate Social and Environmental Responsibility in the Field of Culture includes Purpose and Objectives, Principles, Principles and Scope, Institutional, Implementation, Corporate Social and Environmental Responsibility Programs in the Culture Sector, Community Participation, Awards, Coaching, and Oversight, Dispute Resolution. The purpose of the drafting of this Regional Regulation is in order to increase the Company's awareness of the implementation of Social and Environmental Responsibility in the Cultural Sector in Banyuwangi Regency; Meet the development of legal needs in the community regarding the Social and Environmental Responsibilities of the Cultural Sector; and Strengthening Social and Environmental Responsibilities that have been regulated in various laws and regulations. The purpose is:

a. The realization of clear boundaries on the Social and Environmental Responsibilities of the Cultural Sector Company and the parties who are the perpetrators,

b. Fulfillment of the implementation of Corporate Social and Environmental Responsibility in the Field of Culture in accordance with the prevailing laws and regulations in one coordination, 
c. The realization of legal certainty and protection for business people in conducting the Social and Environmental Responsibility of Cultural Sector Companies in an integrated and efficient manner.

d. The company is protected from illegal levies committed by parties who are not authorized and/or irresponsible,

e. Increased positive image of the company's presence in the midst of the community environment,

f. The realization of the synergy of the implementation of Social and Environmental Responsibility with sustainable development programs in the region while still taking into account the sustainability of environmental functions, economic growth and poverty reduction,

g. The realization of the structured and comprehensive sustainability of the Social and Environmental Responsibility Program, and the programmed plan of the Regional Government to appreciate the business world that has carried out Social and Environmental Responsibility by giving awards and facilitating administrative services.

In the implementation of the Corporate Social and Environmental Responsibility, the planned scope of the field is to include funding assistance for the implementation of social welfare, compensation for recovery and/or improvement of environmental functions, health, education and spurring community-based quality economic growth in harmony with government programs area. In order to ensure that the social and environmental responsibility programs run well the government facilitates the establishment of the Social and Environmental Responsibility Implementing Forum of the Cultural Sector Company which will prepare the program and report to the Regent and DPRD regarding the implementation and evaluation of activities.

The Corporate Social and Environmental Responsibility in the Field of Culture includes Program "Father Foster company" on "Patronage and Environmental and Social Arts Studio. In order to ensure that the community participates in this program there are articles that regulate the participation of the community, namely: The community can participate in the implementation of the Corporate Social and Environmental Responsibility Program in the form of Culture in the form of: submission of suggestions, suggestions, input in the process of preparing the Social Responsibility program and Corporate Environment in the Culture Sector; and complaints about the implementation of the Corporate Social and Environmental Responsibility in the Field of Culture that is not in accordance with the programs and/or activities that have been determined.

At the end of the material, the Regional Regulation regulates the awards that can be given to companies that have carried out social and environmental responsibility programs as well as the obligations of the Regent to conduct guidance and supervision of these activities in order to ensure the intended program runs according to purpose and purpose at the beginning.

\section{Conclusion}

Based on the study as described in previous chapters, the following conclusions can be drawn:

1. Some companies in Banyuwangi Regency have carried out corporate social and environmental responsibilities in the form of charity;

2. The FGD Forum selects the Cultural CSR fund-flow model. Modeling the flow of funds through the built studio. This model is a model that provides guidance to art groups. This model will benefit the art studio more. Like CSR fund distribution for the 
development of small businesses, this model also has the purpose of growing and developing existing studios in order to continue to preserve indigenous culture and culture through the existing art studios.

3. The FGD Forum recommends that the results of the academic manuscript will be set forth in amendments to Regional Regulation No.3/2014 concerning Corporate Social Responsibility.

4. The objectives of the Corporate Social and Environmental Responsibility regulation through this regional regulation are to provide direction in the formulation of regulatory norms in the regulations concerning the Corporate Social and Environmental Responsibility in the Field of Culture, to harmonize the regulation of norms in regional regulations in accordance with academic norms, theoretical and juridical, and provide an explanation of the framework and objectives of regulatory norms in the regulation of regional regulations on Corporate Social and Environmental Responsibilities in the Cultural Sector.

\section{Acknowledgment}

The Directorate of Research and Community Service, Directorate General of Research and Development Strengthening of the Ministry of Research, Technology and Higher Education in accordance with the Fiscal Year 2018 Research Contract Number SP DIPA042.06.1.401516/2018 December 5, 2017.

\section{References}

Ambadar. (2008). CSR in Practices in Indonesia Realizing Business Concern. Jakarta: PT Elek Media Komputerindo.

Harmoni., and Andriyani, A. (2008). Consumer Assessment of Corporate Social Responsibility (CSR) Companies. Journal of Business Economics.13 (1).

Mapisangka, A. (2009). Implementation of CSR on Community Life Welfare.JESP, 1(1).

Marnelly, T. R. (2012). Corporate Social Responsibility (CSR) Review of Theories and Practices in Indonesia. Journal of Business Applications, 2(2).

Miles, M., and Huberman, A. M. (2002). The Qualitative Researcher Companion. India: SAGE Publications Inc.

Sari, R. A. (2012). Effect of Company Characteristics on CSR Disclosure on Manufacturing Companies Listed on the Indonesia Stock Exchange. Nominal Journal, 1(1).

Paramita, R. W. D. (2012). Corporate Social Responsibility (CSR): An overview of the concepts and pros of CSR contra.

Paramita, R. W. D. (2013). The influence of company characteristics on Corporate Social Responsibility (CSR).

Paramita, R. W. D. (2014). The Influence of Corporate Social Responsibility (CSR) on Earnings Response Coefficient (ERC).

Paramita, R. W. D. (2015). Application of Corporate Social Responsibility (CSR) to Communities Around the Company: Qualitative Study.

Paramita, R. W. D. (2018). Cultural CSR in perceptions of cultural preservation. Scientific Journal of Applied Sciences of SYNERGY, 8(1).

Wibisono, Y. (2007). Dissecting CSR Concepts and Applications. East Java: Fascho Publishing. 